\title{
IMPROVEMENT OF ANALYSIS AND DESIGN OF ROAD PAVEMENTS USING NEPHELINE SLUDGE
}

\author{
Irshat Mukharryamov ${ }^{1 *}$, Gleb Averchenko² \\ 1Saint Petersburg State University of Architecture and Civil Engineering \\ Vtoraja Krasnoarmeyskaya st., 4, Saint Petersburg, Russia \\ ${ }^{2}$ Peter the Great St. Petersburg Polytechnic University \\ Polytechnicheskaya st., 29, Saint Petersburg, Russia
}

*Corresponding author: mr.irshat@mail.ru

\begin{abstract}
Introduction: Predicting possible and arising defects in pavement layers made of new construction materials is an important task in the operation of any transport infrastructure facility. Purpose of the study: The study is aimed at performing a literature review, regulatory and practical analysis of the road pavement structure operation, and analysis of the operation of cement-containing pavement layers. The obtained results will be applied to pavements made with the use of nepheline sludge in order to derive a general equation that will reveal insights into a model for the prediction of the structure service life depending on various factors. Methods: The methodological framework of this study is information on the theory and practice of predicting the service life of cement-containing pavement layers. The study is based on the existing and applicable equations of mathematical models. Results: We analyze the operation of pavement structures with respect to defects (macro and micro defects) formation as well as factors affecting the structure service life. Dependence of the strain capacity on the modulus of elasticity of sludge ground and the bending strength as well as dependence of the self-hardening coefficient on the structure service life are shown; factors affecting the structural durability are noted. An overview of the equation for the specific strain energy of structural bonds in a composite material is presented. We also derive a generalized equation of the service life of a structure taking into account a number of factors and set a task solved at the development of models that are the closest to real conditions.
\end{abstract}

\section{Keywords}

Nepheline sludge, prediction of the structure service life, road pavement, structural durability, self-healing, selfcompaction, micro-cracks, slow strength gain.

\section{Introduction}

In the development of design and engineering solutions, specialists in design, construction and operating organizations that ensure the life cycle of roads shall objectively predict, foresee and control possible and arising deformations in the structure of road pavements by means of existing tools of mathematical modeling and other analysis methods. The majority of current methods, equations and models are insufficient since they do not completely take into account real parameters of the traffic flow and ever-changing weather conditions, as well as relevant parameters of moisture transfer and temperature behavior in the road bed - pavement structure system. As Nosov noted (1997), these parameters predetermine the destructive nature of cement-containing surfaces due to the gradual accumulation of microdamage. This is applicable both to the road surface, reinforced road foundation, and subgrade.

In another work (Nosov, 2013), the author emphasizes the objective nature of a solution to the task of determining the service life $\left(T_{\text {ser }}\right)$ of the road pavement. The actual service life $T_{\text {ser }}$ is less than the estimated one $\left(T_{e s t}\right)$.
When new construction materials are used for pavements, including nepheline sludge (NS, alumina production waste) used in road foundations, it is important to predict (calculate) the $T_{\text {ser }}$ value in pavement structure development. While in case of traditional pavements, it is possible to use $T_{\text {ser }}$ for similar structures, then in order to calculate $T_{\text {ser }}$ of pavement structures made using a new material, it is necessary to study test road sections, which is time-consuming and expensive. Therefore, it is required to calculate $T_{\text {ser }}$ using empirical equations confirmed by laboratory tests that are similar to real processes.

\section{Subject, tasks, and methods}

The subject of the study is the self-healing ability (recombination) of nepheline sludge and its positive impact on the service life of road structures (Mukharryamov, 2017). The article solves the following tasks: analyzing the state of application of nepheline sludges in the road industry, taking into account their self-healing ability; deriving a generalized equation to predict the service life of road pavements made using nepheline sludges. In the 
course of the study, methods of planning univariate and multivariate theoretical experiments were used.

\section{Results and discussion}

When determining the strength characteristics of a road foundation made using sludge and subject to intense impact from vehicles, it is necessary to take into account the specifics of the behavior of a new type of foundation, its physical, mechanical, chemical and thermal properties. A typical road foundation has a heterogeneous structure. This is due to the fact that it consists of various construction materials (native soils, native rock materials, crushed stone of various sizes, gravel-sand mixtures, limestone, and others) that interact with each other through friction and cementation.

As opposed to lean concrete, sand-and-cement mix, and other cement-containing structural layers that are highly brittle and hard, a layer made using nepheline sludge is more elastic-plastic, characterized by high crack resistance at dynamic loads from vehicles, and hinders intense crack formation. Nepheline sludge has special physical and chemical characteristics: the crack resistance of rolled nepheline sludge whose brittleness varies from 0.2 to 0.8 is conditioned by its specific strain capacity (Mukharryamov, 2019a). This is due to the shock-absorbing effect of sludge grains that have significant microporosity (up to $30 \%$ ) making it possible to diffuse concentrated stresses at the tip of a subcritical micro crack. The brittleness of nepheline sludge rarely reaches 1.0. The crack resistance of nepheline sludge is conditioned not by Griffith's energy criterion but by the strain capacity that controls the subcritical growth of main cracks (Kalashnikov et al. 1995).

$$
D=\frac{R_{\text {compression }}}{E_{\text {layer }}^{\text {sluge }}}
$$

where $D$ is the strain capacity, [relative values],

$R_{\text {compression }}$ is the estimated value of tensile strength in bending of a reinforced material in a layer of the road structure or road bed, [MPa],

[MPa].

$E_{\text {layer }}^{\text {sludge }}$ is the modulus of elasticity of sludge ground,

Since the crack resistance of a layer depends on the strain capacity, it is required to introduce a coefficient that will record the loss of strength in a sludge ground layer after temperature shrinkage.

Sludge slowly gains strength, hardens gradually, and layers made with the use of sludge have a tendency towards recombination (self-healing). S. N. Zhurkov (Zhurkov, 1968) states that lean concrete, sand-andcement mix, and other cement-containing structural layers do not possess an ability for self-healing after bond breaking, as opposed to structural layers made using nepheline sludge.

Self-hardening in time occurs due to the hydration of the main component of nepheline sludge $-\beta$-dicalcium silicate $2^{*}\left(2 \mathrm{CaO} \cdot \mathrm{SiO}_{2}\right)$. Self-hardening is a selfinduced increase in the strength of structural bonds in a solid material during its use (Federal Road Agency
(Rosavtodor), 2015). Conventional local and other stone materials are cohesionless (discrete) materials that do not have structural bonds between the particles, do not resist tension and are destroyed under loading with irreversible displacement. Nepheline sludge is subject to the aggregation of smaller (less than $0.314 \mathrm{~mm}$ ) grains with large grains. There are natural and structural bonds. Industrial Road Guidance Document ODM 218.3.0432015 (Federal Road Agency (Rosavtodor), 2015) suggests introducing a special indicator - the predicted modulus of elasticity of the foundation material $\left(E_{f f}\right)$.

$$
E_{f t}=E_{0} \cdot \alpha
$$

where $\alpha$ is the self-hardening coefficient.

Using the value of the predicted modulus of elasticity of the foundation material $\left(E_{f f}\right)$, the value of the design modulus of elasticity of the subgrade $\left(E_{\text {sub }}\right)$ and design thickness $\left(h_{0}\right)$, the predicted total modulus of elasticity of the road structure $E_{r e q}^{\min t}$ after self-hardening is determined according to Industrial Road Regulations ODN 218.046-01.

The relationship used for determining the selfhardening coefficient, given in the corresponding regulatory document (Federal Road Agency (Rosavtodor) 2015), is very important in the subsequent development of the ideas, equations and mathematical model of $\mathrm{V}$. P. Nosov for the case of using nepheline sludge in the structural layer of road pavements.

$$
\alpha=0.3642 \cdot \ln \left(T_{\text {ser }}\right)+1.37
$$

where $T_{\text {ser }}$ is the service life of a road structure at the moment of self-hardening coefficient calculation.

Thus, it is obligatory to take into account the selfhardening coefficient (equations (2) and (3)) when presenting or supplementing the equation used to predict the service life of pavements using sludges.

Sludge represents a structure-forming material in the foundation layer made of a mix of crushed stone and local stone materials, where the upper part of the layer can resist shear and bear vertical loads. This leads to an increased service life of the whole pavement.

The above specifics of nepheline sludge used in layers of road structures should be taken into account when determining/clarifying/updating the service life of composite road structures (Mukharryamov, 2019b).

Before describing the model for the prediction of the service life of pavements with nepheline sludge, which will be used to make a hypothesis about the service life, it is necessary to find the sources that negatively affect the pavement structure in general and determine due to what factor the destruction occurs.

Factors that affect durability $(D)$ and have a random impact on the structure as a whole are as follows:

1. heterogeneity of materials;

2. increased stresses in composite materials due to various origin of components, which leads to microdamage;

3. alternating moisturization/drying, freezing/defrosting; precipitations; air humidity;

4. solar radiation;

5. rapid changes in temperatures; air temperature; 
6. impact of osmotic pressure; cloud amount; wind speed;

7. highly scattered loads from vehicles.

When determining the service life of a pavement, it is necessary to take into account all the above factors to the maximum degree. The research conducted by V. P. Nosov and S. N. Zhurkov to derive the equation to calculate the pavement service life can be used as the basis for the model.

According to the theses and equation suggested by S.N. Zhurkov (1968), the relationship of durability $t$ (time) and $\sigma$ (stress) from $T$ (temperature) is as follows:

$$
t=\tau_{0} \cdot \exp \cdot\left(\frac{V_{0}-n \cdot \sigma}{R-T}\right)
$$

where $\tau_{0}$ is a constant, [ 10-13],

$R$ is the Boltzmann constant, [ 1.38-10-16 erg/degree],

$T$ is temperature (degrees),

$n$ is the coefficient that characterizes the structure and homogeneity of the material (sludge ground layer, sludge-and-crushed stone layer) and is important for the consideration of special nepheline sludge properties,

$V_{0}$ is the potential barrier (energy that brings breakup of atomic bonds).

In a loaded body under the effect of tensile forces, the potential barrier $V_{0}$ will decrease, and the fluctuation energy will start gradually breaking up the structural bonds, creating micro-cracks. The specific strain energy, i.e. the energy to be spent in order to destroy the structure of a layer in the process of its deformation to a certain degree, can act as an indicator of the destruction of structural bonds (Zadneprovskiy, 2016). In terms of math, this indicator is expressed as the ratio between the energy and the volume where structural bonds are destroyed:

$$
A_{s}=\frac{A}{V}=\sigma \cdot \varepsilon
$$

where $A_{s}$ is the specific strain energy,

$A$ is the deformation energy,

$V$ is the volume of the deformed layer,

$\sigma$ is the ultimate stress,

$\varepsilon$ is the relative strain.

Presumably, if the load decreases further, the time spent for the accumulation of structural failures and occurrence of this type of deformation will increase. In this case, the total specific energy spent for the destruction of the layer structure will consist of the sum of the energies spent at each change of temperature (the temperature factor that affects the pavement service life is taken into account):

$$
A_{s}=\sum_{1}^{n} A_{s i}=\sum_{1}^{n} \sigma_{i} \cdot \varepsilon_{i}
$$

The above is in line with the concept of the "damage degree" introduced by V. P. Nosov (Nosov, 2013). In lean concrete, sand-and-cement mix, and other cementcontaining layers, damage is accumulated gradually. This process results in micro-cracks. The length of micro-cracks grows until a certain moment when they become a single micro-crack. At the place of its origin, stresses increase.
It is a so-called stress concentration, which accelerates the further growth. Crack development leads to pavement destruction. Such a process of the gradual accumulation of defects under the effect of alternating stresses is called cyclic fatigue of cement-containing layers of the pavement structure. In cement-containing layers, large cracks and cracks growing in width (when the process has ended) develop along a weakened section (with the maximum stress-strain state). It should be noted that in sludge, due to slow gain in strength, small cracks (when the process continues) reform concrete till its maximum strength, and destruction of concrete starts only after that.

The process of sludge strength gain due to the dynamic effect of the load and compaction together with the development of micro-cracks each time a vehicle passes the pavement leads to sludge activation and layer reformation (slow and gradual) until the formation of a finely grained sludge-and-concrete mix. Two processes occur in sludge after the paving and one-year operation:

1. gradual crack formation;

2. crack healing in parallel to the first process.

The above processes are directly reflected in the equation and model to calculate the pavement service life since the components of nepheline sludge activation and the factor of dampened crack growth will be taken into account.

In accordance with the theory suggested by V. P. Nosov (Nosov, 1980a, 1980b) and cyclic fatigue of cement-containing layers of the pavement structure, the level of the stressed state in a cycle $(\rho)$ depends on the relationship between the maximum stress at single loading and the ultimate strength at single loading.

$$
\rho=\frac{\sigma_{\max }}{R}
$$

There is a stable correlation between the level of the stressed state and the number of cycles before the destruction of a sample $(N)$ :

$$
N=F \cdot\left(\frac{\sigma_{\max }}{R}\right)=F \cdot \rho
$$

where $F$ is the coefficient characterizing the relationship.

The number of cycles depends on the load cycle characteristic, and the load cycle characteristic is the $\sigma_{\min }$ ' $\sigma_{\max }$ ratio in a cycle.

Stresses caused by loads from the movement of vehicles, which occur in structures, vary since the traffic flow consists of different vehicles with different carrying capacity, different axle loads, different position of the wheels relative to the road edge, different condition of the subgrade, road surface temperature, etc. This is why the value of tensile stresses in an arbitrarily fixed moment $t$ is random, i.e. the function of stress changes in time is random.

In order to find $N$ (the ultimate number of cycles of loads for a pavement that is in a stressed state characterized by an arbitrary random function), defects should be summed.

$$
\alpha_{i}=\frac{1}{N_{i}}
$$


where $N_{i}$ is the cycle of load application (determined by means of the stress-cycle diagram), $\alpha_{i}$ is a single defect.

The process of layer (primarily, surface) destruction can be represented as a process of the accumulation of single defects caused by each cycle of application of axle loads from vehicles moving on the road (cumulative model by V. V. Bolotin) (Bolotin 1981).

The damage degree according to V. P. Nosov is as follows:

$$
D=\sum_{i=1}^{C} \alpha_{i}
$$

where $C$ is the number of repeated loads for a certain period of time.

Therefore, at $D<1$, we observe pavement material behavior without destruction; at $D=1$, the material is damaged since the threshold value of $N$ is reached.

Equations (9), (10) make it possible to predict the performance of road surfaces and foundations. The more $D(t)$ approaches 1 , the faster the destruction of the road surface will be and the less residual performance the pavement structure will have at this point in time.

One of the conclusions made by a number of experts (Nosov, 2013) is as follows: the width of a cementcontaining layer (slab) is the most important factor that predetermines cracking and $T_{s e r}$. This should be taken into account when designing composite pavements.

Foreign authors suggest an equation that accurately determines the value of cracking $(C)$, which directly depends on vehicles (the number of wheel loads with the load per wheel of $4.082 \mathrm{t}$ ) and the slab width:

$$
C=2.8 \cdot N \cdot H^{6}
$$

where $N$ is the number of interactions between the pavement and the wheels,

$H$ is the slab (layer) width, in inches ( 1 inch $=0.0254 \mathrm{~m}$ ).

The foreign scientists derived this equation through a number of experiments and analysis of previous experience, but with different climate conditions. That is why, when this equation is used to calculate the pavement service life in Russia, it is necessary to introduce some adjusting factors or clarify the equation due to: I - heterogeneity of the materials and soils comprising the subgrade and pavement, II - variability of climate conditions during road operation, and III - traffic flow parameters, which lead to the fact that we have to predict $T_{\text {ser }}$ on the basis of many formalities and assumptions (Nosov, 2013).

It would be insufficient to use traditional equations to determine the service life of road pavement in terms of its reliability since they do not completely take into account parameters of the structure, physical and mechanical properties of the materials and soils comprising the subgrade, and natural features of the road location.

In his paper on the analysis and consideration of the dynamic interaction between concrete road surfaces with the road foundation, V. A. Chernigov (Chernigov, 1963) presents an equation to determine the limit number of impacts:

$$
\begin{aligned}
\lg N= & \left(R \cdot K_{1}-\frac{6 \cdot P \cdot\left(0.0592-0.09284 \cdot \lg \frac{r}{L}\right)}{H}\right) \\
& \cdot \frac{\lg N_{0}}{R \cdot\left(K_{1}-K_{2}\right)}
\end{aligned}
$$

where $R$ is the ultimate tensile strength in bending, MPa;

$K_{1}$ is the endurance limit corresponding to one load cycle, $K_{1}=0.45$.;

$P$ is the mass of the vehicle affecting a wheel, $\mathrm{t}$;

$r$ is the radius of a circle equivalent to the vehicle wheel imprint;

$L$ is the elastic response, which is calculated using the following equation:

$$
L=H \cdot \sqrt[3]{\frac{E}{6 \cdot E_{0}}}
$$

$N_{0}$ is the base number of cycles when determining the endurance limit.

The widely-known equation, suggested by foreign scientists after a number of new experiments AASHO conducted in 1962, should be taken into account (Fenves et al., 1962). This equation empirically calculates the limit number of axle impacts on the layer $N$ depending on the value of cracking $C$ :

$$
\begin{aligned}
& \lg N=4.7+0.5 \cdot \lg C- \\
& -2.62 \cdot \lg \left(\frac{2 \cdot P}{0.454}\right)+4.84 \cdot \frac{H}{254}
\end{aligned}
$$

where $P$ is the mass of the vehicle affecting a wheel, $\mathrm{t}$;

$C$ is the length of cracks relative to $100 \mathrm{~m}^{2}$ of the road surface, $\mathrm{m}$;

$H$ is the thickness of the road surface, $\mathrm{cm}$.

The equation referenced by V. A. Kudryavtsev (Kudryavtsev et al., 1973) is also important. It takes into account the difference in temperatures at the top and the bottom of the road surface (different temperature stresses):

$$
\begin{gathered}
N=\frac{6 \cdot P \cdot\left(0.0592-0.0928 \cdot \lg \frac{r}{L}\right)}{1.08 \cdot R \cdot H^{2}}- \\
-\frac{E \cdot \alpha \cdot \Delta T}{2.16 \cdot R \cdot\left(1-\mu^{2}\right)} \cdot\left(C_{x}+\mu \cdot C_{y}\right)
\end{gathered}
$$

where $\alpha$ is the coefficient for the longitudinal expansion of concrete (in our case, sludge ground / sludge-andcrushed stone mix foundation/surface);

$\Delta T$ is the difference between the temperatures at the top and the bottom of the slab (the same goes for sludge ground / sludge-and-crushed stone layer);

$E, \mu$ is the modulus of elasticity and Poisson's ratio for concrete / sludge ground / sludge-and-crushed stone layer;

$C_{r}$ and $C_{y}$ are the coefficients that depend on the ratio of the length and width of the slab and the elastic response.

This is why it is necessary to take into account processes affecting the pavement service life to develop 
a model to predict the service life of road pavement made using nepheline sludge.

It is reasonable to divide all the factors into the following three groups: traffic flow parameters, weather conditions' parameters, and structure parameters representing vector projections. Traffic flows have different speeds and different distances from each other. We introduce the following parameters: vehicle type, wheel arrangement, weight distribution on axles and wheels, pressure in tires, speed, lateral position, distance between vehicles.

Weather conditions include solar radiation, air temperature, cloud amount, precipitations, air humidity, wind. Structure parameters characterize the shape and size of the structure elements (road surface, road foundation, subgrade, road bed), as well as the properties of the materials and soils used in the structure. It should be emphasized that under the influence of weather conditions, the structure parameters change, and these changes are so important that stresses caused by vehicle loads can change manifold.

Heterogeneity of a pavement layer occurs due to technological mistakes (insufficient mix compaction, failure to comply with the time limits for curing the mix until compaction, maintaining a new layer after the paving, etc.).

\section{Conclusions}

A pavement layer made using nepheline sludge is characterized by specific strain capacity and crack resistance. Strength is gained slowly. Sludge ground layers of pavement structures have a self-healing advantage in comparison to cement-containing layers. These advantages of sludge ground layers increase the pavement service life in comparison to lean concrete, sandand-cement mixes, and other cement-containing layers.
As a result, the service life remains an important indicator of road structure operation. It can be represented in the form of dependence from various factors (a general equation).

$$
T_{\text {ser }}=f\left(n ; n_{1} ; T^{\circ} C ; W ; P\right)
$$

where $n$ is the homogeneity of the material,

$n_{l}$ is a change in stresses occurring in the structure during its operation taking into account the process of nepheline sludge self-healing,

$T^{\circ} \mathrm{C}$ is changes in the air temperature,

$W$ is the water and temperature conditions of the structure;

$P$ is the dynamic load from the traffic flow.

As for the impact of other factors on the pavement service life, further research of their application to sludge ground layers of pavement is needed.

The main purpose of this study is to address the matter of determining the pavement service life with account for the specifics of nepheline sludge as it is in the structure as a binder (matrix) for local stone materials.

\section{Acknowledgments}

The authors express their gratitude to Boris Nikolayevich Karpov, DSc in Engineering, professor of the Department of Motor Roads, Bridges and Tunnels of the Saint Petersburg State University of Architecture and Civil Engineering for professional advice in the course of the study and for assistance in making the main conclusions.

\section{Funding}

The study was performed without any financial support. 


\section{References}

Bolotin, V.V. (1981). Methods of the probability theory and the theory of reliability in structural analysis. $2^{\text {nd }}$ edition. Moscow: Stroyizdat, $352 \mathrm{p}$.

Chernigov, V. A. (1963). A study of the dynamic interaction of concrete roads with the road bed. Reports of a Scientific and Engineering Meeting on Road Construction. Moscow: SoyuzDorNII, pp. 41-43.

Federal Road Agency (Rosavtodor) (2015). Industrial Road Guidance Document ODM 218.3.043-2015. Guidelines for the use of natural belite sludges in road pavement layers. Moscow: Rosavtodor, $67 \mathrm{p}$.

Fenves, S. J., Veletsos, A. S. and Siess, C. P. (1962) Dynamic studies of bridges on the AASHO test road. Civil Engineering Studies SRS-227. Urbana: University of Illinois, 349 p.

Kalashnikov, V. I., Kochetkov, Yu. A., Stankevich, V. G. and Potapov, K. A. (1995) Binder. Patent No. RU2047576C1.

Kudryavtsev, V. A., Yershov, E. D. and Chetverev, V. G. (1973). Dependence of unsaturated soil moisture transfer factors on the soil humidity, texture and density. Cryosolic Studies: a collection of papers. Issue 13. Moscow: Publishing House of Moscow State University, pp. 176-182.

Nosov, V. P. (1980a). Analysis of cement concrete road surfaces. Moscow: Moscow Automobile and Road Construction State Technical University (MADI), $62 \mathrm{p}$.

Nosov, V. P. (1980b). Prediction of the service life of cement concrete road surfaces. Reliability of roads: a collection of research papers. Moscow: Moscow Automobile and Road Construction State Technical University (MADI).

Nosov, V. P. (1997). Predicting damage to rigid layers of road pavements using mathematical modeling. DSc Thesis in Engineering. Moscow: Moscow Automobile and Road Construction State Technical University (MADI).

Nosov, V. P. (2013). Cement concrete road surfaces. Predicting damage using mathematical modeling: a monograph. Moscow: Moscow Automobile and Road Construction State Technical University (MADI), 228 p.

Mukharryamov, I.R. (2017). Issues concerning the use of nepheline sludge in road constructions. Bulletin of Civil Engineers, 1, pp. 192-197.

Mukharryamov, I.R. (2019a). Investigation of characteristic features of nepheline sludge used in the road construction during the life cycle. Bulletin of Civil Engineers, 3, pp. 161-169. DOI: 10.23968/1999-5571-2018-16-3-161-169.

Mukharryamov, I.R. (2019b). Road clothes with the application of nefeline sludge as a guarantor of the durability of the automobile road. In: Klekovkina, M. P. (ed.) Innovations and durability of transport infrastructure facilities (materials, structures, technologies). Proceedings of the scientific and practical conference, November 14, 2018. Saint Petersburg: Saint Petersburg State University of Architecture and Civil Engineering, pp. 57-59.

Zadneprovskiy, R. P. (2016). About energetics of bodies destruction with regard for their physical state. Tambov University Reports. Series: Natural and Technical Sciences, 21 (3), pp. 826-829. DOI: 10.20310/1810-0198-2016-21-3-826-829.

Zhurkov, S. N. (1968). A kinetic concept of the strength of solid bodies. Bulletin of the Soviet Academy of Sciences, 3, pp. 46-52. 


\title{
СОВЕРШЕНСТВОВАНИЕ РАСЧЕТА И КОНСТРУИРОВАНИЯ ДОРОЖНЫХ ОДЕЖД С ИСПОЛЬЗОВАНИЕМ НЕФЕЛИНОВОГО ШЛАМА
}

\author{
Иршат Рафисович Мухаррямов ${ }^{1 *}$, Глеб Александрович Аверченко ${ }^{2}$ \\ ${ }^{1}$ Санкт-Петербургский государственный архитектурно-строительный университет \\ 2-ая Красноармейская ул., 4, Санкт-Петербург, Россия \\ ${ }^{2}$ Санкт-Петербургский политехнический университет Петра Великого \\ Политехническая ул., 29, Санкт-Петербург, Россия \\ *E-mail: mr.irshat@mail.ru
}

\begin{abstract}
Аннотация
Прогнозирование возможных и зарождающихся дефектов, в конструктивных слоях дорожных одежд, устроенных из новых строительных материалов, важная задача при эксплуатации любого объекта транспортной инфрраструктуры. Цель исследования: Провести литературный, нормативный и практический анализ процесса работы конструкции дорожной одежды. Анализ работы цементосодержащих конструктивных слоев. Полученные результаты перенести на конструкции дорожных одежд, устроенных с применением нефелинового шлама для формирования фрормулы общего вида, которая дает понимание модели прогнозирования срока службы конструкции в зависимости от различных фракторов. Методы: Методологическая основа данного исследования представляет из себя базу информации по положениям теории и практики развития прогнозирования сроков службы цементосодержащих слоев дорожных одежд. В исследовании за основупринимались уже существующие иприменяемые формулы математических моделей. Результаты: Проанализирована работа конструкций дорожных одежд на предмет образования дефектов (макро- и микродефекты ), а также на предмет влияющих фракторов, на срок службы конструкции. Показана зависимость деформативности от модуля упругости шламогрунта и величины сопротивления растяжению при изгибе; приведена зависимость коэффициента самоупрочнения от срока службы конструкции; также отмечены факторы, влияющие на долговечность конструкции. Обзор формулы удельной энергии деформации структурных связей в композитном материале. Выведена обобщенная формула срока службы конструкции с учетом ряда влияющих факторов, а также поставлена основная задача, решаемая при разработке моделей более близких к реальным ситуациям.
\end{abstract}

\section{Ключевые слова}

Нефелиновый шлам, прогнозирование срока службы конструкции, дорожная одежда, долговечность конструкции, самозалечивание, самоуплотнение, микротрещины, медленный набор прочности. 